Volume 3 Nomor 2, Agustus 2018, halaman 101-114

\title{
STUDI KOMPARATIF TENTANG PENINGKATAN KEMAMPUAN PEMECAHAN MASALAH MATEMATIS SISWA MTS YANG MEMPEROLEH PEMBELAJARAN DENGAN PENDEKATAN PROBLEM POSING DAN DIRECT INSTRUCTION
}

\author{
THE COMPARATIVE STUDY ABOUT ENHANCEMENT OF \\ PROBLEM SOLVING ABILITIES OF MTS STUDENTS UNDER \\ PROBLEM POSING APPROACH AND DIRECT INSTRUCTION
}

\author{
Rini Trisnawati \\ SMP Negeri 12 Pekanbaru, Jl. Guru H. Sulaiman No.37 Pekanbaru, \\ trisnawatirini62@yahoo.com
}

\begin{abstract}
ABSTRAK
Penelitian ini bertujuan untuk menelaah peningkatan kemampuan pemecahan masalah matematis siswa yang memperoleh pembelajaran dengan pendekatan problem posing dan siswa yang Direct Instruction. Penelitian ini merupakan penelitian eksperimen dengan desain penelitian yaitu PretesPost-test two treatment design. Populasi dalam penelitian ini adalah siswa kelas VIII salah satu MTsN di Pekanbaru. Sampel untuk penelitian ini diambil dua kelas sebagai kelas eksperimen dengan menggunakan teknik purposive sampling. Instrumen yang digunakan berupa soal tes kemampuan pemecahan masalah. Temuan penelitian ini adalah: (1) Kemampuan pemecahan masalah matematis siswa yang memperoleh pembelajaran dengan pendekatan Problem Posing lebih baik daripada siswa yang memperoleh Direct Instruction; dan (2) Peningkatan kemampuan pemecahan masalah matematis siswa yang memperoleh pembelajaran dengan pendekatan Problem Posing lebih baik daripada siswa yang memperoleh Direct Instruction.
\end{abstract}

Kata kunci: Kemampuan Pemecahan Masalah Matematis, Pendekatan Problem Posing, Direct Instruction

\begin{abstract}
This study aims to examine enhancement of problem solving ability of the students who got learning with problem posing approach and the students who got direct instruction. This study employed experimental research with Pretest-Post-test two treatment design. The population in this study were class VIII the students of one MTsN in Pekanbaru. For sample for this study, two classes were taken as experimental class by using purposive sampling technique. The instruments which were used were in the forms of problem solving ability tests. The findings of this study were: (1) Mathematical problem solving ability of the students who got learning with Problem Posing approach was better than the students who got Direct Instruction; (2) The enhancement of problem solving ability of the students who got learning with Problem Posing approach was better than the students who get Direct Instruction.
\end{abstract}

Keywords: Mathematical Problem Solving Ability, Problem Posing Approach, Direct Instruction 
How to Cite: Trisnawati, R. (2018). Studi Komparatif Tentang Peningkatan Kemampuan Pemecahan Masalah Matematis Siswa MTs yang Memperoleh Pembelajaran dengan Pendekatan Problem Posing dan Direct Instruction. Mathline: Jurnal Matematika dan Pendidikan Matematika, Vol.3, No.2, 101-114.

\section{PENDAHULUAN}

Kemampuan pemecahan masalah matematis penting untuk dikembangkan karena kemampuan pemecahan masalah matematis dapat membantu menyelesaikan permasalahan yang dihadapi, untuk mengantisipasi perkembangan ilmu pengetahuan dan permasalahan kehidupan sehari-hari. Ruseffendi (1991) mengatakan bahwa "kemampuan pemecahan masalah sangat penting dalam matematika, bukan saja bagi mereka yang dikemudian hari akan mendalami atau mempelajari matematika, melainkan juga bagi mereka yang akan menerapkannya dalam bidang studi lain dan dalam kehidupan sehari-hari”. Pentingnya kemampuan pemecahan masalah juga diutarakan oleh Dahar (2011) yang menyatakan bahwa "kemampuan untuk memecahkan masalah pada dasarnya merupakan tujuan utama proses pendidikan". Tokoh lain yang mengutarakan pentingnya kemampuan pemecahan masalah adalah Hergenhahn \& Olson (2012) "bahwa Salah satu tren utama dalam teori belajar adalah proses kognitif seperti pembentukan konsep, pengambilan resiko, dan pemecahan masalah".

Sumarmo (2013) menjelaskan bahwa pemecahan masalah matematik mempunyai dua makna yaitu: (1) pemecahan masalah sebagai suatu pendekatan pembelajaran, yang digunakan untuk menemukan kembali (reinvention) dan memahami materi, konsep, dan prinsip matematika. Pembelajaran diawali dengan penyajian masalah atau situasi yang kontekstual kemudian melalui induksi siswa menemukan konsep/prinsip matematika; (2) sebagai tujuan atau kemampuan yang harus dicapai, yang dirinci menjadi lima indikator meliputi:

a) mengidentifikasi kecukupan data untuk pemecahan masalah;

b) membuat model matematik dari suatu situasi atau masalah sehari-hari dan menyelesaikannya;

c) memilih dan menerapkan strategi untuk menyelesaikan masalah matematika dan atau di luar matematika;

d) menjelaskan atau menginterpretasikan hasil sesuai permasalahan asal, serta memeriksa kebenaran hasil atau jawaban;

e) menerapkan matematika secara bermakna. 
National Council of Teachers of Mathematics (NCTM, 2000) dalam buku berjudul 'Principles and Standard for School Mathematics' menyatakan bahwa "standar proses pembelajaran matematika terdiri dari pemecahan masalah (problem solving), penalaran dan pembuktian (reasoning and proof), komunikasi matematis (communication), keterkaitan dalam matematika (connection), dan representasi (representation)".

NCTM (2000) memberikan empat standar problem solving (pemecahan masalah), yaitu: (1) siswa mampu untuk membangun pengetahuan matematika yang baru melalui problem solving (pemecahan masalah); (2) siswa mampu untuk menyelesaikan masalah yang muncul di dalam konteks matematika dan konteks lainnya; (3) siswa mampu untuk menerapkan dan menyesuaikan berbagai strategi yang tepat untuk menyelesaikan masalah; (4) siswa mampu untuk mengamati dan merefleksi proses pemecahan masalah matematika. Dalam kehidupan nyata, seseorang yang mempunyai kemampuan pemecahan masalah yang baik dapat memberikan banyak manfaat bagi orang lain.

Polya (1957) dalam bukunya yang berjudul How to Solve It secara garis besar mengemukakan empat langkah utama dalam pemecahan masalah yaitu diuraikan sebagai berikut:

Tabel 1. Langkah-Langkah Dalam Pemecahan Masalah

\begin{tabular}{|c|c|c|}
\hline No & $\begin{array}{l}\text { Langkah-Langkah } \\
\text { Pemecahan Masalah }\end{array}$ & Keterangan \\
\hline 1 & $\begin{array}{l}\text { Memahami masalah } \\
\text { (Understanding the } \\
\text { Problem) }\end{array}$ & $\begin{array}{l}\text { Problem apa yang dihadapi? } \\
\text { Apa yang diketahui? } \\
\text { Apa yang ditanya? } \\
\text { Apa kondisinya? } \\
\text { Bagaimana memilah kondisi-kondisi tersebut? } \\
\text { Tuliskan hal-hal itu, bila perlu buatlah gambar, } \\
\text { gunakan simbol atau lambang yang sesuai. }\end{array}$ \\
\hline 2 & $\begin{array}{c}\text { Menyusun rencana } \\
\text { pemecahan (Devising } a \\
\text { Plan) }\end{array}$ & $\begin{array}{l}\text { Menemukan hubungan antara data dengan hal-hal } \\
\text { yang belum diketahui, atau mengaitkan hal-hal } \\
\text { yang mirip secara analogi dengan masalah. } \\
\text { Apakah pernah mengalami problem yang mirip? } \\
\text { Apakah mengetahui masalah yang berkaitan? } \\
\text { Teorema apa yang dapat digunakan? } \\
\text { Apakah ada pola yang dapat digunakan? }\end{array}$ \\
\hline 3 & $\begin{array}{l}\text { Melaksanakan rencana } \\
\text { (Carrying out the Plan) }\end{array}$ & $\begin{array}{l}\text { Menjalankan rencana untuk menemukan solusi, } \\
\text { melakukan dan memeriksa setiap langkah apakah } \\
\text { sudah benar, bagimana membuktikan bahwa } \\
\text { perhitungan, langkah-langkah dan prosedur sudah } \\
\text { benar. }\end{array}$ \\
\hline 4 & $\begin{array}{l}\text { Memeriksa kembali } \\
\text { (Looking Back) }\end{array}$ & $\begin{array}{l}\text { Melakukan pemeriksaan kembali terhadap proses } \\
\text { dan solusi yang dibuat untuk untuk memastikan } \\
\text { bahwa cara itu sudah baik dan benar. Selain itu } \\
\text { utuk mencari apakah dapat dibuat generalisasi, }\end{array}$ \\
\hline
\end{tabular}




\begin{tabular}{lllr}
\hline No & $\begin{array}{c}\text { Langkah-Langkah } \\
\text { Pemecahan Masalah }\end{array}$ & \multicolumn{3}{c}{ Keterangan } \\
\hline & untuk menyelesaikan masalah yang sama, \\
& menelaah untuk pendalaman atau mencari \\
& kemungkinan adanya penyelesaian lain. \\
\hline
\end{tabular}

Olkin dan Schoenfeld (Sumarmo, 2013) mengemukakan bahwa bentuk soal pemecahan masalah yang baik hendaknya memiliki karakteristik sebagai berikut: (1) dapat diakses tanpa banyak menggunakan mesin, ini berarti masalah yang terlibat bukan karena perhitungan yang sulit; (2) dapat diselesaikan dengan beberapa cara, atau bentuk soal yang open ended; (3) melukiskan ide matematika yang penting (matematika yang bagus); (4) tidak memuat solusi dengan trik; (5) dapat diperluas dan digeneralisasikan (untuk memperkaya eksplorasi).

Indikator pemecahan masalah matematis dalam penelitian ini adalah: (1) mengidentifikasi kecukupan data untuk pemecahan masalah; (2) membuat model matematik dari suatu situasi atau masalah sehari-hari dan menyelesaikannya; (3) memilih dan menerapkan strategi untuk menyelesaikan masalah matematika dan atau di luar matematika; (4) menjelaskan atau menginterpretasikan hasil sesuai permasalahan asal, serta memeriksa kebenaran hasil atau jawaban.

Kemampuan pemecahan masalah pada siswa dapat ditingkatkan dengan penerapan berbagai strategi maupun metode pembelajaran, seperti yang telah dilakukan oleh Yuberta (2013) meneliti penerapan strategi Every One Is A Teacher Here (ETH) dengan pendekatan Problem Posing untuk meningkatkan kemampuan pemecahan masalah matematis dan Self-Concept siswa MTsN. Penelitian ini dilakukan di MTsN 1 di kota Bukittinggi pada tahun ajaran 2012/2013. Sampel pada penelitian ini adalah siswa kelas VIII semester genap. Hasil penelitian ini menunjukkan bahwa (1) peningkatan kemampuan pemecahan masalah matematis siswa yang memperoleh pembelajaran menggunakan strategi ETH dengan pendekatan Problem Posing lebih baik daripada siswa yang memperoleh pembelajaran konvensional; (2) ditinjau dari kemampuan awal matematika siswa (KAM), terdapat perbedaan peningkatan kemampuan pemecahan masalah matematis siswa yang memperoleh pembelajaran menggunakan strategi ETH dengan pendekatan Problem Posing; dan (3) tidak terdapat perbedaan Self-Concept siswa yang memperoleh pembelajaran menggunakan strategi ETH dengan pendekatan Problem Posing dan siswa yang memperoleh pembelajaran konvensional ditinjau dari kemampuan awal matematika siswa (KAM). 
Djamarah (2008) mengemukakan bahwa mengajar bukan tugas yang ringan bagi guru. Konsekuensi dan tanggung jawab guru juga berat. Di kelas guru akan berhadapan dengan sekelompok siswa dengan segala persamaan dan perbedaannya. Sikap dan perilaku siswa bervariasi dengan indikator pendiam, suka bicara, suka mengganggu, aktif belajar, gemar menggambar, gemar menulis, malas dan sebagainya. Sebagai siswa mereka masih memerlukan bimbingan dan pembinaan dari guru agar menjadi anak yang cakap, aktif, kreatif, dan mandiri serta bertanggung jawab atas perbuatannya. Salah satu cara yang dapat digunakan guru dalam mengembangkan kemampuan pemecahan masalah bagi siswa dengan karakter yang berbeda adalah pembelajaran dengan pendekatan problem posing.

Stoyanova \& Ellerton (1996) dan Abu-Elwan (2002) menjelaskan bahwa terdapat tiga kategori pengalaman belajar dalam Problem Posing, yaitu: (1) situasi bebas (free Situations); (2) situasi semi terstruktur (semi-structure sitiations); dan (3) situasi yang terstruktur (structured situations). Stoyanova dan Silver (Pittalis, Christou, Mousoulides, \& Pitta-Pantazi, 2004) memaparkan bahwa terdapat lima kategori pengalaman belajar dalam Problem Posing, yaitu: (1) a problem in general (free situations) (permasalahan secara umum/situasi yang bebas); (2) a problem with a given answer (pertanyaan yang dapat di jawab); (3) a problem that contains certain information (pertanyaan yang memiliki informasi tertentu); (4) questions for a problem situation (pertanyaan yang muncul dari suatu keadaan); dan (5) a problem that fits a given calculations (sebuah permasalahan yang sesuai dengan hasil perhitungan yang diberikan).

Berdasarkan hasil penelitiannya, Silver \& Cai (Haji, 2011) membuat diagram dari berbagai respon yang muncul dalam pendekatan pembelajaran problem posing yaitu sebagai berikut: 


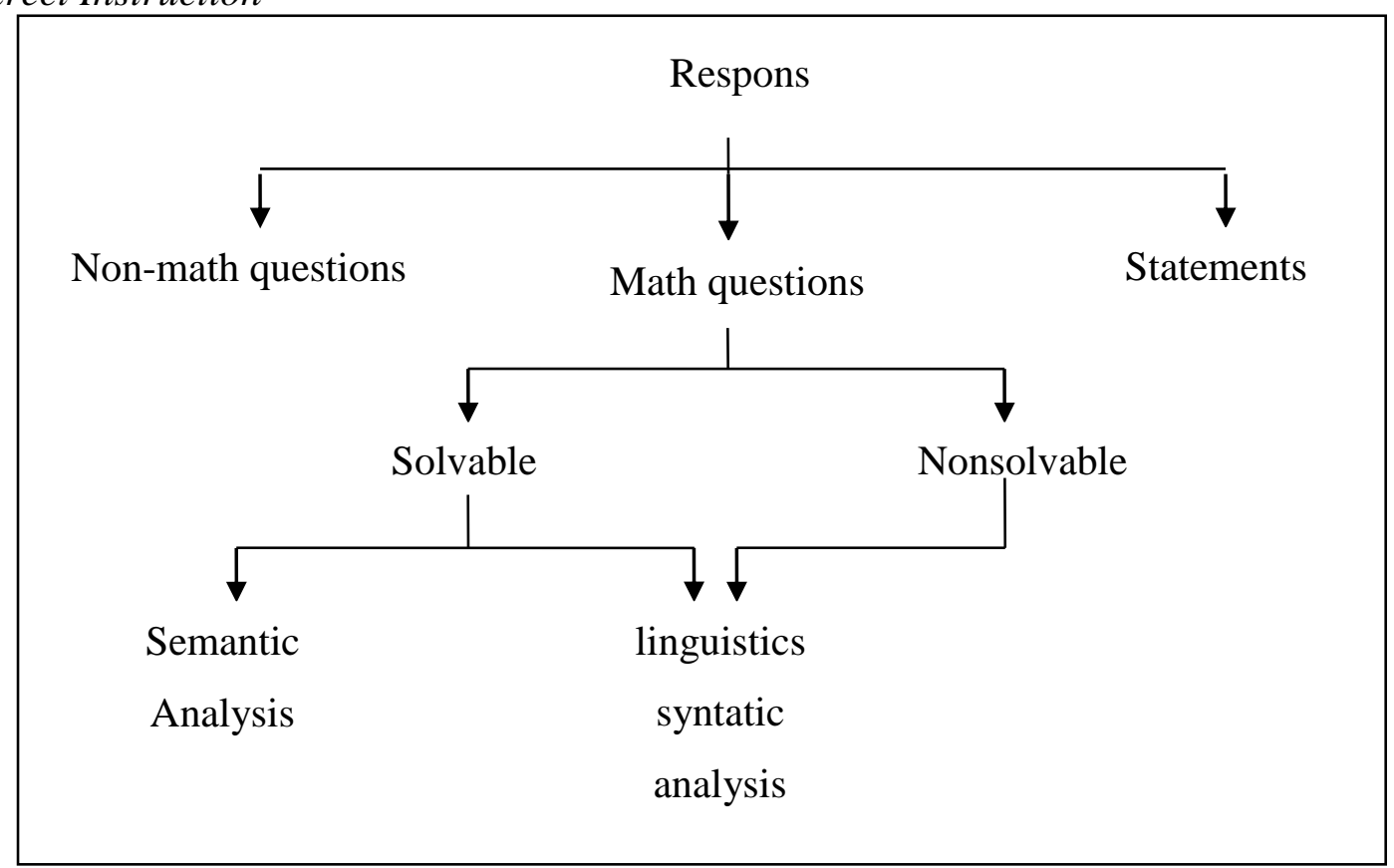

Gambar 1. Jenis Respon Siswa yang Muncul ketika Pembelajaran Problem Posing

Silver (Pittalis, Christou, Mousoulides, \& Pitta-Pantazi, 2004) menjelaskan bahwa berdasarkan kapan terjadinya Problem Posing dapat dibagi menjadi tiga waktu yang berbeda, yaitu: (1) sebelum (prior) penyelesaian masalah, ketika masalah dibangun dari stimulus yang dihadirkan secara khusus dalam bentuk cerita, gambar, diagram, atau dalam bentuk lainnya; (2) selama penyelesaian masalah, ketika siswa mengubah dengan sengaja tujuan-tujuan dan kondisi-kondisi dari masalah; (3) setelah penyelesaian masalah, ketika konteks pengalaman penyelesaian masalah diaplikasikan siswa dalam situasi yang baru.

Auerbach (Sutawidjaja \& Dahlan, 2011) menetapkan lima langkah dalam mengimplementasikan pendekatan Problem Posing, yaitu :

Tabel 2. Langkah-Langkah Pembelajaran Problem Posing

\begin{tabular}{|c|c|c|}
\hline No & Langkah-Langkah & Keterangan \\
\hline 1 & $\begin{array}{c}\text { Gambarkan Situasi } \\
\text { (Describe the Content) }\end{array}$ & $\begin{array}{l}\text { Guru memberikan siswa suatu kode atau tanda. Kode- } \\
\text { kode tersebut merupakan aspek yang vital dalam } \\
\text { problem posing. Guru harus memulai dari hal-hal yang } \\
\text { berkaitan dengan kehidupan sehari-hari siswa. kode- } \\
\text { kode dapat berupa dialog tertulis (contohnya teks yang } \\
\text { diambil dari koran, majalah, buletin, dan lainnya), dapat } \\
\text { juga berupa gambar-gambar (contohnya lukisan, foto, } \\
\text { kolase, kartun,cergam, dan lainnya). }\end{array}$ \\
\hline 2 & $\begin{array}{l}\text { Rumuskan Masalah } \\
\text { (Define the Problem) }\end{array}$ & $\begin{array}{l}\text { Siswa menemukan isu atau masalah dalam kode. Guru } \\
\text { mukin perlu mengulang pertanyaan yang telah } \\
\text { disiapkan. Guru sebaiknya bertanya kepada siswa untuk } \\
\text { memfokuskan siswa hanya pada masalah yang berkaitan } \\
\text { dengan topik atau pokok bahasan. Guru juga dapat } \\
\text { menggunakan masalah lain sebagai ide untuk pengajuan }\end{array}$ \\
\hline
\end{tabular}




\begin{tabular}{|c|c|c|}
\hline No & Langkah-Langkah & Keterangan \\
\hline & & masalah lebih lanjut. \\
\hline 3 & $\begin{array}{l}\text { Pikirkan dan Rasakan } \\
\text { Adanya Masalah } \\
\text { (Personalize the } \\
\text { Problem) }\end{array}$ & $\begin{array}{l}\text { Dalam posisi ini, guru menjadi fasilitator dari diskusi, } \\
\text { seperti memandu siswa untuk mendiskusikan bagaimana } \\
\text { masalah ini berdasarkan apa yang mereka rasakan dan } \\
\text { masalah apa yang membuat mereka memikirkannya } \\
\text { sehingga mereka dapat menyimpan atau } \\
\text { menginternalisasi masalahnya. }\end{array}$ \\
\hline 4 & $\begin{array}{l}\text { Diskusikan Masalah } \\
\text { (Discuss the Problem) }\end{array}$ & $\begin{array}{l}\text { Guru memandu siswa dalam mendiskusikan masalah } \\
\text { yang telah diberikan dan meminta siswa untuk } \\
\text { mendiskusikan tentang mengapa ada suatu masalah dan } \\
\text { bagaimana hal itu mempengaruhi mereka. }\end{array}$ \\
\hline 5 & $\begin{array}{l}\text { Diskusikan Beberapa } \\
\text { Alternatif Pemecahan } \\
\text { (Discuss Alternatives } \\
\text { to the Problem) }\end{array}$ & $\begin{array}{l}\text { Guru harus melatih siswa dalam mengajukan } \\
\text { kemungkinan pemecahan masalah dan mendiskusikan } \\
\text { konsekuensi-konsekuensi dari berbagai macam tindakan } \\
\text { yang akan dilakukan. }\end{array}$ \\
\hline
\end{tabular}

Untuk mengetahui efektifitas pendekatan Problem Posing dalam rangka meningkatkan kemampuan pemecahan masalah matematis siswa, maka perlu dibandingkan dengan pendekatan lain. Pendekatan Problem Posing digunakan di kelas ekperimen yang pertama sedangkan Direct Instruction digunakan di kelas eksperimen yang kedua.

Berdasarkan penelitian yang dilakukan oleh Good dan Brophy (Muijs \& Reynolds, 2008) menghasilkan suatu kesimpulan bahwa Direct Instruction merupakan metode terbaik untuk mengajarkan tentang aturan, prosedur, dan keterampilan dasar khususnya untuk murid-murid belia. Tetapi bukan berarti bahwa Direct Instruction adalah metode terbaik untuk digunakan di semua keadaan.

Tujuan direct instruction adalah untuk membantu siswa mempelajari berbagai keterampilan dan pengetahuan dasar yang dapat diajarkan secara langsung langkah demi langkah (Arends, 2008). Pembelajaran Langsung (Direct Instruction) dimaksudkan untuk menuntaskan dua hasil balajar siswa yaitu penguasaan pengetahuan yang distrukturisasikan dengan baik dan penguasaan keterampilan (Arends, 2008). Adapun langkah-langkah Direct Instruction menurut Joyce, et al (2009), yaitu:

Tabel 3. Langkah-Langkah Direct Instruction

\begin{tabular}{lll}
\hline No & $\begin{array}{c}\text { Langkah- } \\
\text { Langkah }\end{array}$ & \multicolumn{1}{c}{ Keterangan } \\
\hline & & $\begin{array}{l}\text { a. Guru menentukan materi pelajaran } \\
\text { b. Guru menentukan tujuan pelajaran }\end{array}$ \\
1. & Orientasi & $\begin{array}{l}\text { c. Guru menentukan prosedur pengajaran } \\
\text { d. Guru meninjau pelajaran sebelumya }\end{array}$ \\
\hline 2. Presentasi & $\begin{array}{l}\text { a. Guru menjelaskan konsep atau keterampilan baru } \\
\text { b. Guru menyampaikan presentasi visual atas tugas yang } \\
\text { diberikan }\end{array}$ \\
\hline
\end{tabular}



Siswa MTs yang Memperoleh Pembelajaran dengan Pendekatan Problem Posing dan Direct Instruction

\begin{tabular}{|c|c|c|}
\hline No & $\begin{array}{l}\text { Langkah- } \\
\text { Langkah }\end{array}$ & Keterangan \\
\hline & & c. Guru memastikan pemahaman siswa \\
\hline 3. & $\begin{array}{l}\text { Praktik } \\
\text { yang } \\
\text { terstruktur }\end{array}$ & $\begin{array}{l}\text { a. Guru menuntun siswa dengan contoh praktik dalam } \\
\text { beberapa langkah } \\
\text { b. Siswa merespon pertanyaan yang diberikan guru } \\
\text { c. Guru memberikan feedback (koreksi terhadap kesalahan dan } \\
\text { memperkuat praktik yang telah benar) }\end{array}$ \\
\hline 4. & $\begin{array}{l}\text { Praktik di } \\
\text { bawah } \\
\text { bimbingan } \\
\text { guru }\end{array}$ & $\begin{array}{l}\text { a. Siswa melakukan praktik secara semi-independent } \\
\text { b. Guru menggilir siswa untuk melakukan praktik dan } \\
\text { mengamati siswa yang sedang praktik } \\
\text { c. Guru memberikan umpan balik berupa pujian, bisikan, } \\
\text { maupun petunjuk }\end{array}$ \\
\hline 5. & $\begin{array}{l}\text { Praktik } \\
\text { mandiri }\end{array}$ & $\begin{array}{l}\text { a. Siswa melakukan praktik mandiri di rumah atau di kelas } \\
\text { b. Guru menunda respon balik dan memberikannya di akhir } \\
\text { rangkaian praktik } \\
\text { c. Praktik mandiri dilakukan beberapa kali dalam periode } \\
\text { waktu yang lama }\end{array}$ \\
\hline
\end{tabular}

Berdasarkan latar belakang yang telah dipaparkan di atas, maka penelitian ini bertujuan untuk mengetahui apakah kemampuan pemecahan masalah matematis siswa yang memperoleh pembelajaran dengan pendekatan problem posing lebih baik dibandingkan siswa yang memperoleh direct instruction.

\section{METODE PENELITIAN}

Penelitian ini dilakukan pada dua kelas sebagai subjek penelitian, kedua kelas ini diberikan pretes dan postes. Penelitian ini merupakan penelitian eksperimen dengan disain "Pretes-Post-test two treatment design". Pola rancangan (Cohen, et al., 2007) digambarkan sebagai berikut:

Kelas Eksperimen $_{1} \quad: \mathrm{O}_{1} \quad \mathrm{X}_{1} \quad \mathrm{O}_{2}$

Kelas Eksperimen $_{2} \quad: \mathrm{O}_{1} \quad \mathrm{X}_{2} \quad \mathrm{O}_{2}$

Keterangan:

$\mathrm{O}_{1}$ : Pretes kemampuan pemecahan masalah matematis siswa

$\mathrm{O}_{2}$ : Postes kemampuan pemecahan masalah matematis siswa

$\mathrm{X}_{1}$ : Pembelajaran matematika dengan pendekatan Problem Posing

$\mathrm{X}_{2}$ : Pembelajaran matematika dengan direct instruction

Penentuan sampel dilakukan dengan cara purposive sampling (teknik pengambilan sampel pertimbangan) yaitu teknik pengambilan sampel yang digunakan peneliti jika peneliti mempunyai pertimbangan-pertimbangan tertentu di dalam pengambilan sampelnya atau pengambilan sampel untuk tujuan tertentu (Riduwan \& Akdon, 2010). Sampel pada 
penelitian ini adalah kelas eksperimen pertama yaitu siswa kelas VIII.7 dan kelas eksperimen kedua yaitu siswa di kelas VIII.8 dengan mengambil kelas yang sudah ada agar tidak mengganggu proses pembelajaran.

Penelitian ini dilaksanakan selama satu bulan (delapan kali pertemuan). Pertemuan pertama adalah pelaksanaan pretes, pertemuan ke-dua sampai pertemuan ke-tujuh adalah treatment di kelas VIII.7 yaitu pembelajaran dengan pendekatan problem posing dan di kelas VIII.8 yaitu dengan direct instruction, sedangkan pada pertemuan terakhir (pertemuan ke-delapan) dilaksanakan postes pada kedua kelas tersebut.

Pretes dilakukan untuk mengetahui kemampuan awal pemecahan masalah matematis siswa pada kedua kelas yang diteliti sebelum dilaksanakannya pembelajaran dengan pendekatan problem posing dan direct instruction. Sedangkan postes dilakukan untuk mengetahui peningkatan kemampuan pemecahan masalah matematis siswa pada kedua kelas yang diteliti setelah dilaksanakannya pembelajaran dengan pendekatan problem posing dan direct instruction. Tes kemampuan pemecahan masalah dalam penelitian ini terdiri dari empat soal uraian. Setiap soal tersebut mencerminkan satu indikator dari kemampuan pemecahan masalah.

\section{HASIL DAN PEMBAHASAN}

Pembahasan hasil penelitian ini didasarkan pada faktor-faktor yang dicermati dalam penelitian ini. Faktor-faktor tersebut meliputi pembelajaran dengan pendekatan problem posing, direct instruction, dan kemampuan pemecahan masalah.

Jika dilihat dari pencapaian kemampuan pemecahan masalah matematis siswa pada kedua kelas eksperimen untuk setiap indikator kemampuan pemecahan masalah, maka diperoleh : 

Siswa MTs yang Memperoleh Pembelajaran dengan Pendekatan Problem Posing dan Direct Instruction

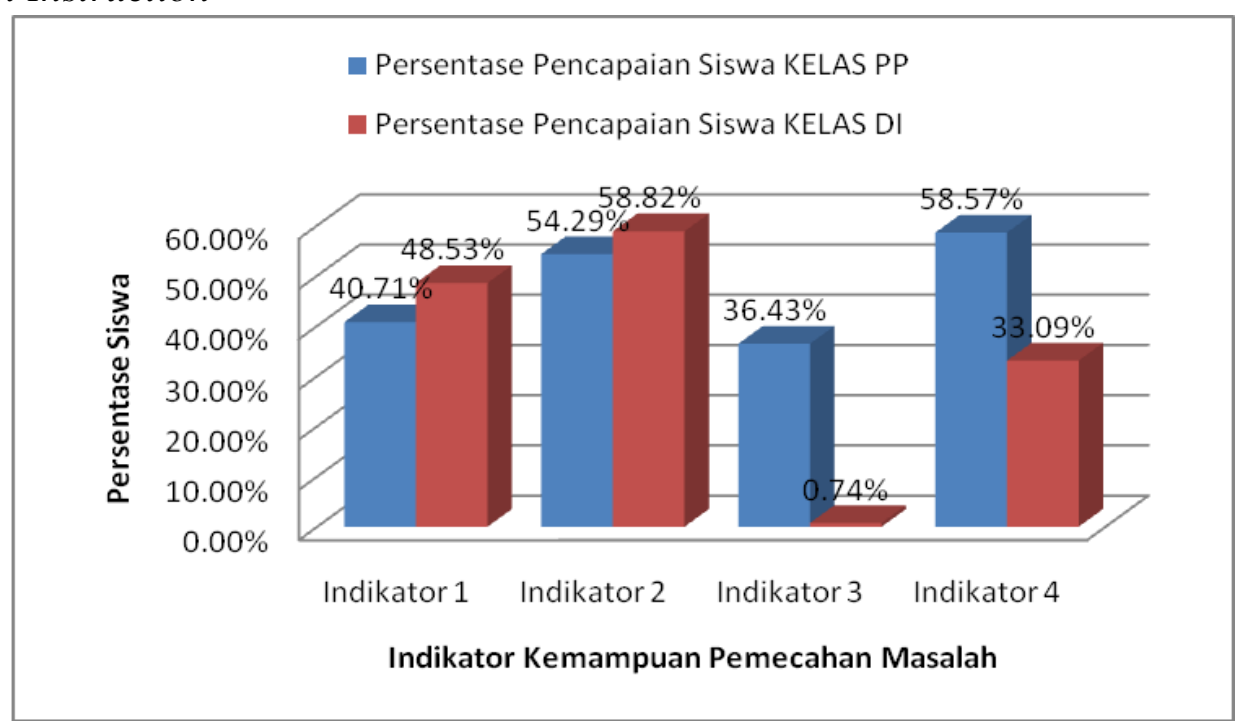

Gambar 2. Diagram Persentase Pencapaian Kemampuan Pemecahan Masalah Matematis Siswa untuk Setiap Indikator pada Kedua Kelas Eksperimen

Temuan ini menunjukkan bahwa indikator ketiga yang paling sedikit dikuasai siswa di kedua kelas eksperimen. Artinya siswa di kedua kelas eksperimen masih kesulitan dalam memilih dan menerapkan strategi untuk menyelesaikan masalah matematika dan atau di luar matematika.

Soal nomor dua, yang merupakan soal yang mencerminkan indikator kedua, yaitu membuat model matematika dari suatu situasi atau masalah sehari-hari dan menyelesaikannya. Terdapat lebih dari $50 \%$ siswa di kedua kelas eksperimen yang menguasai indikator tersebut. Berikut ini adalah jawaban siswa untuk soal nomor dua pada postes kemampuan pemecahan masalah di kedua kelas eksperimen: 
Perhatikan gambar di bawah ini!

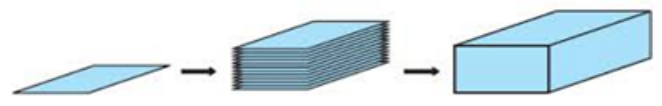

Ahmad memiliki 100 lembar kertas yang berukuran $18 \mathrm{~cm} \times 25 \mathrm{~cm} \times$ $0,1 \mathrm{~cm}$ yang akan dimasukkan ke dalam kardus yang volumenya $4500 \mathrm{~cm}^{3}$. Jika luas permukaan atas kertas sama dengan luas permukaan alas kardus, tentukanlah:

a) Tinggi kardus tersebut!

b) Berapa buah kardus yang diperlukan Ahmad untuk memasukkan semua kertas yang dimilikinya?

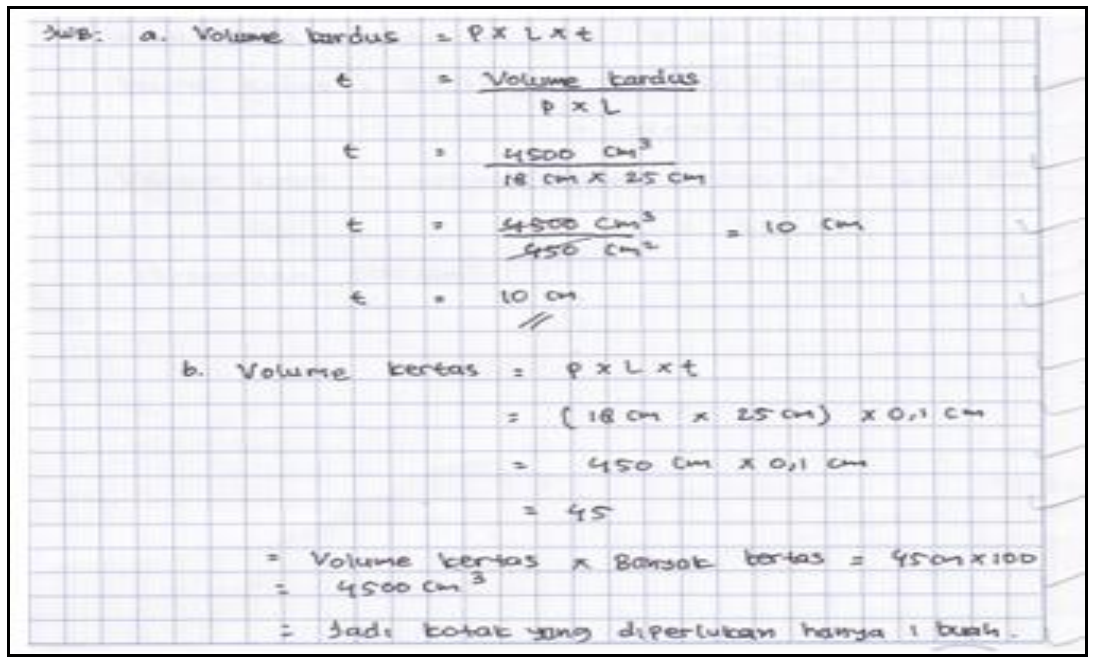

Gambar 3. Hasil Jawaban Postes Kemampuan Pemecahan Masalah Matematis Salah Satu Siswa di Kelas PP 

Siswa MTs yang Memperoleh Pembelajaran dengan Pendekatan Problem Posing dan Direct Instruction

Perhatikan gambar di bawah ini!

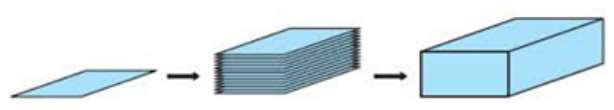

Ahmad memiliki 100 lembar kertas yang berukuran $18 \mathrm{~cm} \times 25 \mathrm{~cm} \times$ $0,1 \mathrm{~cm}$ yang akan dimasukkan ke dalam kardus yang volumenya $4500 \mathrm{~cm}^{3}$. Jika luas permukaan atas kertas sama dengan luas permukaan alas kardus, tentukanlah:

a) Tinggi kardus tersebut!

b) Berapa buah kardus yang diperlukan Ahmad untuk memasukkan semua kertas yang dimilikinya?

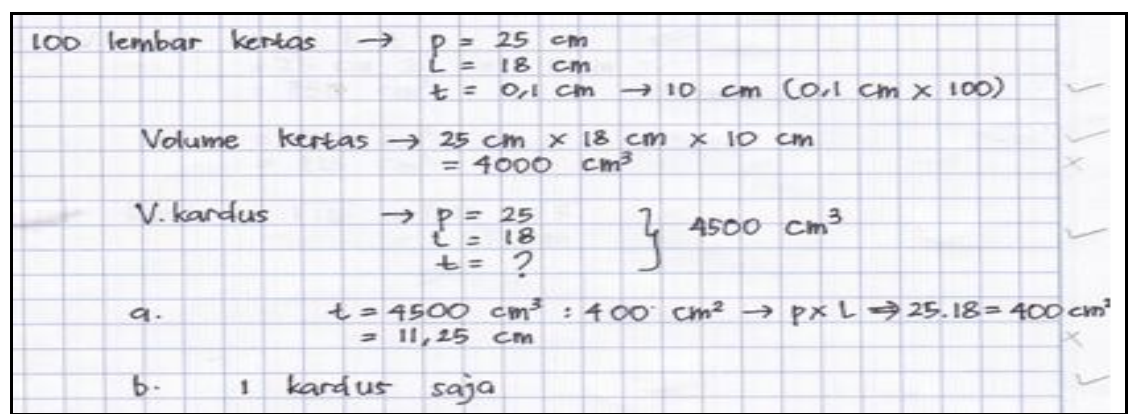

Gambar 4. Hasil Jawaban Postes Kemampuan Pemecahan Masalah Matematis Salah Satu Siswa di Kelas DI

Jawaban kedua siswa tersebut menunjukkan bahwa siswa pada kedua kelas eksperimen telah mampu membuat model matematika dari situasi yang diberikan. Namun masih ada siswa yang kurang teliti dalam melakukan perhitungan sehingga tidak mendapatkan skor maksimal.

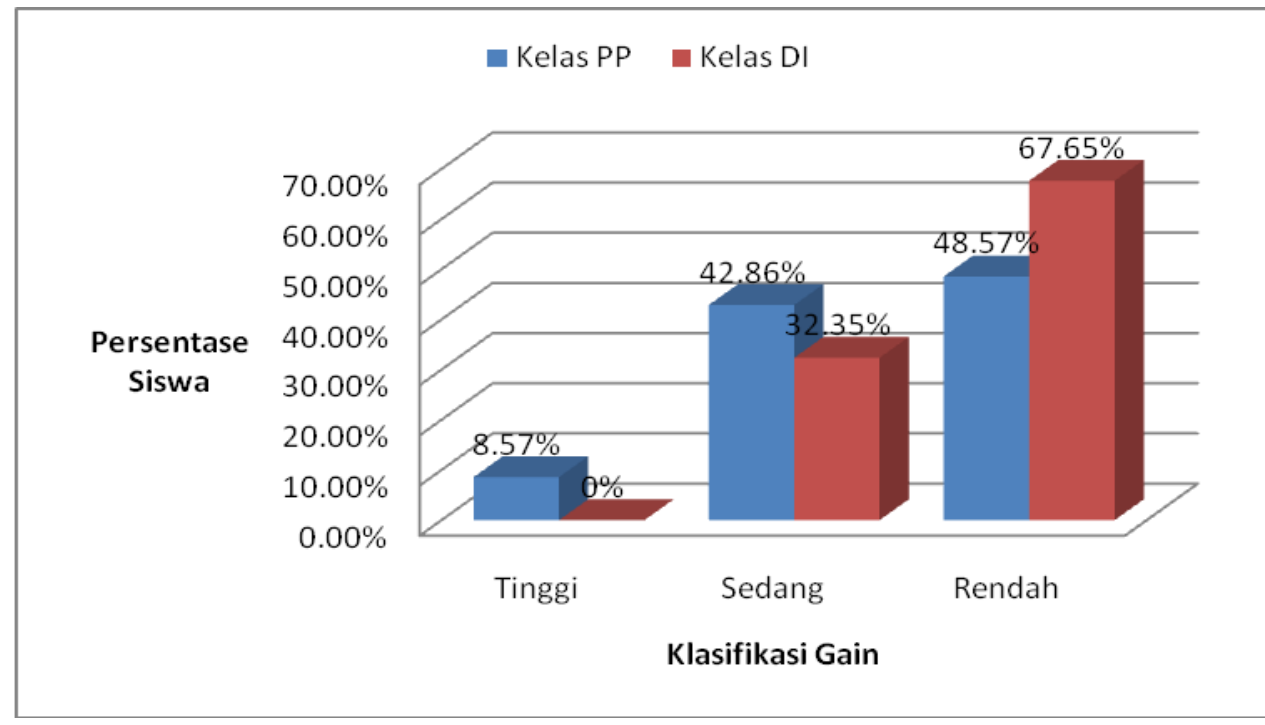

Gambar 5. Diagram Presentase Klasifikasi Gain Kemampuan Pemecahan Masalah Matematis Siswa.

Jika dilihat dari nilai deviasi standar Gain kemampuan pemecahan masalah matematis siswa pada kelas eksperimen satu (PP) lebih baik daripada nilai standar deviasi 
Gain kemampuan pemecahan masalah matematis siswa pada kelas eksperimen dua (DI). Hal tersebut menunjukkan bahwa peningkatan kemampuan pemecahan masalah matematis siswa pada kelas eksperimen satu yaitu siswa yang memperoleh pembelajaran dengan pendekatan Problem Posing lebih baik daripada peningkatan kemampuan pemecahan masalah matematis siswa pada kelas eksperimen dua yaitu siswa yang memperoleh Direct Instruction. Temuan ini sejalan dengan temuan Yuberta (2013) yang menyatakan bahwa peningkatan kemampuan pemecahan masalah matematis siswa yang memperoleh pembelajaran menggunakan strategi Every One Is A Teacher Here dengan pendekatan Problem Posing lebih baik daripada siswa yang memperoleh pembelajaran konvensional.

\section{KESIMPULAN}

Kesimpulan yang diperoleh dari penelitian ini adalah kemampuan pemecahan masalah matematis siswa yang memperoleh pembelajaran dengan pendekatan Problem Posing lebih baik daripada siswa yang memperoleh Direct Instruction, dan peningkatan kemampuan pemecahan masalah matematis siswa yang memperoleh pembelajaran dengan pendekatan Problem Posing lebih baik daripada siswa yang memperoleh Direct Instruction.

\section{DAFTAR PUSTAKA}

Abu-Elwan, R. (2002). Effectiveness of Problem Posing Strategies on Prospective Mathematics Teachers' Problem Solving Performance. Journal of Science and Mathematics Education in Southeast Asia. 25, (1), 56-69.

Arends, R. I. (2008). Learning To Teach: Belajar Untuk Mengajar (Diterjemahkan oleh Helly Prajitno Soetjpto \& Sri Mulyatini Soetjpto). Yogyakarta: Pustaka Pelajar.

Cohen, L., Manion, L. \& Morrison, K. (2007). Research Methods in Education (6 th edition). USA and Canada: Routledge.

Dahar, R. W. (2011). Teori-Teori Belajar dan Pembelajaran. Jakarta: Erlangga.

Djamarah, S. B. (2008). Psikologi Belajar. Jakarta: Rineka Cipta.

Haji, S. (2011). Pendekatan Problem Posing dalam Pembelajaran Matematika Di Sekolah Dasar. Jurnal Kependidikan Triadik. 14, (1), 55-63.

Hergenhahn, B. R. \& Olson, M. H. (2012). Teori belajar (Diterjemahkan oleh Triwibowo.B.S). Jakarta: Kencana.

Joyce, Weil \& Calhoun. (2009). Models of Teaching: model-model pengajaran (Diterjemahkan oleh Achmad Fawaid \& Ateilla Mirza). Yogyakarta: Pustaka Pelajar.

Muijs, D. \& Reynolds, D. (2008). Efective Teaching: teori dan aplikasi (Diterjemahkan oleh Helly Prajitno Soetjpto \& Sri Mulyatini Soetjpto). Yogyakarta: Puataka Pelajar.

NCTM. (2000). Principle and Strandars for School Mathematics. United States: NCTM.

Pittalis, Christou, Mousoulides, Marios Pittalis \& Pitta-Pantazi. (2004). A Structural Model For Problem Posing. Proceding Of The 28th Conference of the International Group for The Psychology of Mathematics Educations, 4, 49-56. 
114 Studi Komparatif Tentang Peningkatan Kemampuan Pemecahan Masalah Matematis Siswa MTs yang Memperoleh Pembelajaran dengan Pendekatan Problem Posing dan Direct Instruction

Polya, G. (1957). How To Solve. United States: Princeton University Press.

Riduwan \& Akdon. (2010). Rumus dan Data dalam Analisis Statistika. Bandung: Alfabeta.

Ruseffendi, H. E. T. (1991). Pengantar Kepada Membantu Guru Mengembangkan Kompetensinya dalam Pengajaran Matematika untuk Meningkatkan CBSA. Bandung: Tarsito.

Stoyanova, E. \& Ellerton, N. F. (1996). A Framework for Research Into Student's Problem Posing in School Mathematics. [Online]. Tersedia: http://www.merga.net.au/documents/RP_Stoyanova_Ellerton_1996.pdf [12Oktober 2013].

Sumarmo, U. (2013). Kumpulan Makalah: berpikir dan disposisi matematik serta pembelajarannya. Bandung: Universitas Pendidikan Indonesia.

Sutawidjaja, A. \& Dahlan, J. A. (2011). Pembelajaran Matematika. Jakarta: Universitas Terbuka.

Yuberta, F. (2013). Penerapan Strategi Every One Is A Teacher Here Dengan Pendekatan Problem Posing Untuk Meningkatkan Kemampuan Pemecahan Masalah Matematis dan Self-Concept Siswa MTsN. Tesis. SPs-UPI Bandung: Tidak diterbitkan. 